\title{
Composition and abundance of decapod crustaceans in mixed seagrass meadows in the Paraguaná Peninsula, Venezuela
}

\author{
Joany Mariño ${ }^{1,2}$ (D) , María Daniela Mendoza' (iD \& Beatriz López-Sánchez (D)
}

\author{
1. Laboratorio de Ecología Acuática, Centro de Ecología, Instituto Venezolano de Investigaciones Científicas (IVIC). Apartado Postal 20632, 1020-A \\ Caracas, Venezuela (bealopezsanchez@gmail.com; blopez@ivic.gob.ve) \\ 2. Theoretical Biology Laboratory and Marine Chemosymbiosis Laboratory, Department of Biology, Memorial University of Newfoundland. St. John's, NL A1B 3X9, \\ Canada.
}

Received 4 July 2017

Accepted 10 January 2018

Published 26 March 2018

DOI: $10.1590 / 1678-4766 e 2018004$

\begin{abstract}
Thalassia testudinum and Halodule wrigthii are the dominant seagrasses in the Caribbean, being common across shallow shorelines, either as monospecific or as intermixed meadows. Among the macrofauna associated with these beds, crustaceans are considered essential for the whole ecosystem functioning. However, knowledge about the associated community of decapod crustaceans in assemblages of T. testudinum and $H$. wrigthii is still scarce, particularly outside of protected areas. Here we report eight new decapod species for the Paraguaná Peninsula (Falcón State, Venezuela) in association with intermixed seagrass beds: Achelous tumidulus Stimpson, 1871, Alpheus aff. floridanus Kingsley, 1878, Chorinus heros (Herbst, 1790), Clibanarius antillensis (Stimpson, 1859), Clibanarius sclopetarius (Herbst, 1796), Latreutes parvulus (Stimpson, 1866), Panopeus occidentalis Saussure, 1857, and Processa fimbriata Manning \& Chace, 1971. These records represent habitat extensions and fill gaps in the geographical distribution of the species along the northern coast of South America. Furthermore, we found that statistical differences in decapod species abundance and composition are likely to be caused by the joint action of coverage and heterogeneity of the beds. Our results indicate that typical Caribbean species were the most influential in the community; nevertheless, the abundance of juvenile Penaeus schmitti Burkenroad, 1936 was notable, since they have rarely been found in these habitats. This finding highlights the role of non-protected areas as nursery habitats for economically important species. Our results show that seagrass meadows in the Paraguaná Peninsula reflect overall good health when compared to other Caribbean zones, representing an important habitat for the maintenance of crustacean populations.
\end{abstract}

KEYWORDS. Caridean and penaeid shrimps, new records, Falcón state, Halodule, Thalassia.

RESUMEN. Composición y abundancia de crustáceos decápodos en praderas mixtas de hierbas marinas en la península de Paraguaná, Venezuela. Thalassia testudinum y Halodule wrigthii son las hierbas marinas dominantes en el Caribe, siendo comunes en costas someras, tanto en monocultivos como en cultivos mixtos. Entre la macrofauna asociada a estas comunidades, los crustáceos son considerados esenciales para el funcionamiento del ecosistema. Sin embargo, el conocimiento sobre la comunidad de crustáceos decápodos asociada a praderas mixtas de T. testudinum y H. wrigthii es escaso, en particular fuera de zonas protegidas. En este trabajo presentamos ocho nuevas especies de decápodos para la Península de Paraguaná (estado Falcón, Venezuela) asociados a praderas mixtas de hierbas marinas: Achelous tumidulus Stimpson, 1871, Alpheus floridanus Kingsley, 1878, Chorinus heros (Herbst, 1790), Clibanarius antillensis (Stimpson, 1859), Clibanarius sclopetarius (Herbst, 1796), Latreutes parvulus (Stimpson, 1866), Panopeus occidentalis Saussure, 1857, y Processa fimbriata Manning \& Chace, 1971. Estos registros representan extensiones de hábitat y completan brechas en la distribución geográfica de las especies a lo largo de la costa septentrional de Sudamérica. Diferencias estadísticas en la abundancia y composición de las especies de decápodos fueron posiblemente causadas por la acción conjunta de cobertura y heterogeneidad de las praderas. Las especies más influyentes en la comunidad son típicas para el Caribe; no obstante, la abundancia de juveniles de Penaeus schmitti Burkenroad, 1936 fue notable, puesto que raramente han sido encontrados en estos hábitats. Este hallazgo resalta el rol de áreas no protegidas como hábitats de cría para especies de importancia comercial. Nuestros resultados muestran que las praderas de hierbas marinas en la Península de Paraguaná reflejan un buen estado en comparación con otras zonas del Caribe, y representan un hábitat importante para el mantenimiento de las poblaciones de crustáceos.

PALABRAS-CLAVE. Camarones carídeos y peneidos, nuevos registros, estado Falcón, Halodule, Thalassia.

Seagrass meadows are a conspicuous and widely spread marine ecosystem in temperate and tropical zones (ÁvILA et al., 2015); they have been ranked among the most valuable ecosystems in the biosphere, since they provide important ecological services, such as maintaining the coastline against erosion, and offering habitat for diverse species that are considered endangered or that have economic importance (SHORT et al., 2007). In spite of this, seagrasses are experiencing a global decline in abundance (and therefore there is also a reduction of its associated community), which is mainly attributed to anthropogenic activities, such as sedimentation due to deforestation, an excessive production of nutrients in coastal waters, as well as habitat destruction, invasive species, pollution, and hydrological alterations (CABAÇO et al., 2008; Ávila et al., 2015). Because of their sensibility to disturbances, seagrasses are considered good 
bioindicators to monitor the health of marine ecosystems, being important components of restoration and conservation projects (Short \& Wyllie-Echeverria, 1996; Short \& NeCKLes, 1999).

In the Caribbean area, in the subtidal zone, Thalassia testudinum Banks ex König (Hydrocharitaceae) is the dominant seagrass species, followed by Halodule wrigthii Ascherson (Cymodoceaceae); and they both occur either as monocultures or as intermixed cultures (SHORT et al., 2001). The benthic macrofauna associated with Thalassia spp. meadows is composed of a diverse and abundant community of crustaceans, mollusks, annelids, and fishes (THAYER et al., 1984, BAUER, 1985a,b; SOGARD, 1989), with a density and distribution that is determined by biological factors (e.g. related to the seagrass, such as coverage, biomass, and leaf length, which increase the complexity of the habitat and its superficial area; as well as predation, competition, and food availability) and physical factors (e.g. dissolved oxygen, light, sedimentation rate, wind disturbance) (BITTERSOTO, 1999; Bostrom \& BonSDORFF, 2000; JimÉNEZ et al., 2005; YAMADA et al., 2007). Comparatively, the information regarding Halodule spp. and its associated community is scarce, and there is even less information concerning dual assemblages of $T$. testudinum and $H$. wrigthii.

The presence of macrophytes is a major factor that influences the presence and abundance of crustaceans, and it has been shown that vegetated microhabitats consistently support greater species richness and abundance when compared with unvegetated areas (LEWIS, 1984; CASARES \& CREED, 2008). The species richness, abundance, and composition of crustaceans in seagrass meadows is affected by the habitat complexity; notwithstanding, the responses vary along with the characteristics of the specific community and taxa (LEWIS, 1984; BITTER-Soto, 1999). Decapod crustaceans have an important role in structuring the community associated with beds of $T$. testudimun, as they constitute an important food item in the diet of several juvenile stages of fishes and other crustaceans (HeCK \& WeinsteIn, 1989). In this aspect, epibenthic macroinvertebrates and their predators represent the main link of matter and energy to higher trophic levels (THAYER et al., 1984). In addition, their capacity as pollinators of T. testudimun during their larval stages has recently been confirmed by experimental evidence (TUSSENBROEK et al., 2016). Hence, their presence and abundance is essential to the whole ecosystem functioning (LewIS, 1984; ZUPO \& NeLSON, 1999).

In Venezuela, decapod crustaceans are known mainly from the work of RodRíGUEZ (1980). In Falcón state, which covers almost a third of the nation's shoreline (approximately $708 \mathrm{~km}$, from a total of $3964 \mathrm{~km}$ ), SÁNCHEZ et al. (1994) have made inventories of the penaeid and caridean shrimps, while CARMONA-SuÁrez \& CONDE (1996) have described the community of brachyuran crabs. However, little attention has been given to brachyurans living within Thalassia testudinum meadows (CARMONA-SuÁrez, 2000), and the most researched area is Morrocoy National Park (CARMONASuÁrez, 2000; Miloslavich et al., 2005). Consequently, there are still localities without detailed studies regarding the taxocenoses associated with seagrass meadows; in particular those outside of protected areas. The aim of the present study was to determine the decapod species associated with mixed seagrass meadows in two zones of the eastern Paraguaná Peninsula (Falcón state, Venezuela). We focus on the richness and abundance of species, relating the effect that biological and physical factors of the meadows have on this associated community. We give a broad ecological account of the ecosystem, in context with other localities in the Caribbean. We also consider the geographical distribution of the decapods, showing that eight species are new records for the state, thus filling gaps in their previous distribution.

\section{MATERIALS AND METHODS}

Study site. The studied shoreline at Falcón State is located in the western zone of Venezuela (Fig. 1), and it is composed of a variety of marine ecosystems, namely: rocky and sandy shores, mangrove swamps, coastal lagoons, salt marshes, and seagrass meadows (CARMONA \& CONDE, 1989; SÁNCHEZ et al., 1994). This region is characterized by abnormally arid conditions, with scarce precipitation and nutrient input (CARMONA-SUÁREZ, 2007). The rainfall is markedly seasonal and restricted to a few months of the year: the dry season occurs from January to September, with a monthly mean rainfall of $8.6 \mathrm{~mm}$; the rainy season occurs between October and December, with a monthly mean rainfall between 60 to $80 \mathrm{~mm}$ (López et al., 2011). The annual average air temperature is $27.7^{\circ} \mathrm{C}$, and the annual mean wind speed is $10 \mathrm{~km} / \mathrm{h}$, varying according to the season (GODDARD \& PiCARD, 1976).

Seagrass beds are well developed in five shallow localities at the Paraguaná Peninsula (CARMONA \& CONDE, 1989), two of which were chosen as study areas: El Supí $\left(12^{\circ} 0{ }^{\prime} 51.2^{\prime \prime} \mathrm{N}, 69^{\circ} 49^{\prime} 59.9^{\prime \prime} \mathrm{W}\right)$ and Adícora $\left(11^{\circ} 56^{\prime} 37.2^{\circ} \mathrm{N}\right.$, $\left.69^{\circ} 48^{\prime} 7.4^{\prime \prime} \mathrm{W}\right)$. These sites are approximately $10 \mathrm{~km}$ apart, located outside of protected areas and close to tourist attractions. Both localities are sandy beaches with a low profile and muddy waters, delimited on the eastern side (windward side) by fringing coral reefs, which protect the seagrass meadows from the strong waves that predominate in the area (CARMONA \& CONDE, 1989; CARMONA-SuÁrez, 2007). Samplings were conducted in May 2013, during the predominant dry season.

Specimen collection. We conducted intensive samplings during the nighttime using a manual push net with an opening of $1 \mathrm{~m}$ (width) $\mathrm{x} 0.5 \mathrm{~m}$ (height), and a mesh size of $1 \mathrm{~mm}$ (modified from MANNING, 1975). We took five replicas, corresponding to a fringe of approximately $1 \mathrm{~m} \times 13$ $\mathrm{m}$ (i.e. a sampling unit), in random zones within the meadows at each study site. Collected organisms were transferred to labeled plastic bags and fixed in situ using ethanol (70\%) with glycerin $(1 \%)$. In the laboratory, we identified individuals to the lowest possible taxonomic level using specialized keys (i.e. Chace, 1972; Rodríguez, 1980; Abele \& Kim, 1986; PéreZ-FARFANTE \& KeNSLEy, 1997). Specimens were 


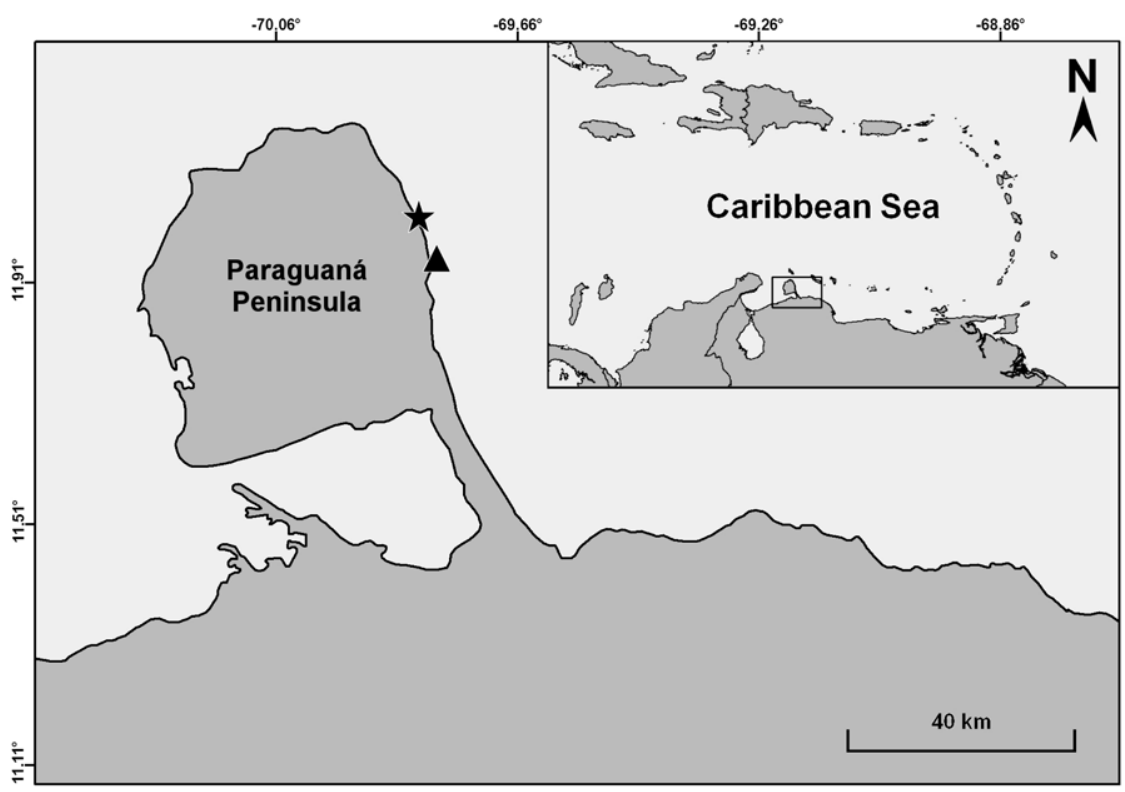

Fig. 1. Location of the sampling sites at the Paraguaná Peninsula, Falcón State, Venezuela ( $\star$, El Supí; $\mathbf{\Lambda}$, Adícora).

deposited in the Colección de Crustáceos Decápodos "Dr. Gilberto Rodríguez" (CCDGR), of the Instituto Venezolano de Investigaciones Científicas (IVIC), Caracas-Venezuela.

Seagrass meadow characterization. We measured the total area of the meadows using a Global Positioning System (GPS) receiver. Structural aspects of the seagrass meadows were sampled in four randomly distributed replicas through $1 \mathrm{~m}^{2}$ quadrats (with divisions every $10 \mathrm{~cm}$ ) per each sampling site, which allowed us to measure vegetation coverage and number of short-shoot stems. We measured stem density by $\mathrm{m}^{2}$ by counting the number of short-shoot stems and leaf blades in the corners and in the center of the quadrat (corresponding to an area of $500 \mathrm{~cm}^{2}$ ), and later extrapolating the result. We took four random samples of Thalassia testudinum (corresponding to an area of $100 \mathrm{~cm}^{2}$ ) and preserved them in cold. In the laboratory, we used those samples to determine the length, width, and leaf area for each blade of every short-shoot. We calculated the Leaf Area Index (LAI) following CARICOMP (CARIBBEAN COASTAL Marine Productivity Program, 1993-2003) methods (LiNTON \& FisheR, 2004).

Environmental parameters. We measured salinity (ppm) using a temperature compensated refractometer, and water temperature $\left({ }^{\circ} \mathrm{C}\right)$ and dissolved oxygen $(\mathrm{mg} / \mathrm{L})$ through a multi-parameter probe. We measured the sea level and depth (m) with a graduated pole fixed to the sea bottom. We took all measurements after sunset, before the biological surveys.

Data analysis. We calculated decapod abundance as the total number of individuals per site, density as the number of individuals per $\mathrm{m}^{2}$, and richness as the number of species per study site. $t$-student tests were done to evaluate differences between localities according to the percentage of vegetation cover and density of decapods. Additionally, in order to determine the dissimilarity between the sites according to species richness and abundance, we used a Bray-Curtis similarity matrix with a nonparametric multidimensional scaling ordination (NMDS), and an analysis of similarities (ANOSIM). Moreover, to distinguish the contribution of each species to the observed differences in the samples, we calculated the similarity percentages (SIMPER). These analyses were implemented through the package vegan (OKSANen et al., 2017) in R language (R Development CoRE TEAM, 2017).

\section{RESULTS}

Decapod community. During the surveys we collected a total of 706 individuals of carcinofauna, belonging to the orders Decapoda (584), Amphipoda (69), Isopoda (45), and Stomatopoda (8). In this paper we focus only on the decapods, which were distributed as 531 individuals from the El Supí site and 48 from the Adícora site. The richness was represented by 22 species in 13 families (Tab. I). Overall, the most abundant taxa were the caridean and penaeid shrimps, particularly species of the families Hippolytidae, Alpheidae, and Penaeidae.

Inter-site comparison. The most abundant family at El Supí was Hippolytidae, which accounted for $84 \%$ of the total decapods in the site; the dominant species were Latreutes parvulus (Stimpson, 1866), and Alpheus packardii Kingsley, 1880. At Adícora, the most abundant family was Penaeidae, which represented $59 \%$ of the total decapods; the dominant species was Penaeus schmitti Burkenroad, 1936, occurring mostly as juveniles and only present at this locality. At both sites the second most common family was Alpheidae, contributing to $14 \%$ of the total decapods for Adícora and to $2 \%$ for El Supí. The least common species were Clibanarius sclopetarius (Herbst, 1796), Clibanarius antillensis (Stimpson, 1862), and Omalacantha bicornuta (Latreille, 1825), which were found exclusively at the Adícora site. 
The relative density of decapods was statistically different between the sites ( $t$-test, $\mathrm{p}<0.05)$, the highest value being found at El Supí $\left(7.83 \pm 1.28 \mathrm{ind} / \mathrm{m}^{2}\right)$ and the lowest at Adícora $\left(0.70 \pm 0.07 \mathrm{ind} / \mathrm{m}^{2}\right)$. The abundance of decapods was also statistically different between the sites (ANOSIM, $\mathrm{p}<0.01, \mathrm{R}=0.084$ ). The species that contributed the most to the dissimilarity were Latreutes parvulus, Hippolyte obliquimanus Dana, 1852, and Alpheus packardii, which together amounted to $81 \%$ of the community (Tab. II). The two localities were separated by a NMDS analysis with $95 \%$ confidence intervals (Fig. 2), which showed that dissimilarities in richness, abundance, and species composition enable differentiating the sites.

Vegetation and physicochemical parameters. The predominant species of seagrass at both localities was Thalassia testudinum. At El Supí the meadow was entirely intermixed with Halodule wrightii. Conversely, the meadow at Adícora was formed by continuous and monospecific T. testudinum, except for its southernmost portion where it was gradually replaced by a low-density bed of $H$. wrightii. At both sites, the meadows were established on a sandy calcareous substrate, which showed remains of the green calcareous alga Halimeda sp. El Supí site was notable because of the presence of flowers in the T. testudinum, the occurrence of several species of macroalgae (i.e. Padina sp., Ulva sp., and Codium sp.), and isolated coral boulders (Porites sp.).

The percentage of vegetation cover between sampling sites resulted significantly different $(t$-test, $\mathrm{p}<0.05)$, with coverage ranging from 87 to $100 \%$ for El Supí, and from 69 to $97 \%$ for Adícora. The average values of $T$. testudinum leaf length, leaf width, LAI, and short-shoot stem density were overall higher for the bed at El Supí than for the Adícora locality (Tab. III). The depths of the meadows varied approximately from 17 to $60 \mathrm{~cm}$, the shallowest portions occurring at Adícora and the deepest at El Supí. No significant differences were observed between sites in the environmental parameters $(t$-test, $\mathrm{p}>0.05)$ (Tab. III).

Tab. I. Decapod species associated with mixed seagrass meadows by sampling site at the eastern Paraguaná Peninsula, Venezuela. Among the collected material, juvenile specimens that could not be identified to species were labeled as $\mathrm{sp}$. The recorded caridean larvae were included in the statistical analyses; however, we omit them for the calculation of total species richness. Species number per family in parentheses; the juvenile individuals were not quantified for the total number of species $(*$, new addition to the carcinofauna of Falcón State, Venezuela).

\begin{tabular}{|c|c|c|c|c|c|}
\hline Suborder & Superfamily & Family & Species & El Supí & Adícora \\
\hline \multirow[t]{5}{*}{ Dendrobranchiata } & Penaoidea & Penaeidae (4) & Penaeus schmitti Burkenroad, 1936 & & 23 \\
\hline & & & Penaeus cf. brasiliensis Latreille, 1817 & & 2 \\
\hline & & & Penaeus cf. duorarum Burkenroad, 1939 & 1 & 1 \\
\hline & & & Penaeus sp. (juvenile) & 11 & 4 \\
\hline & & & Metapenaeopsis sp. & 1 & \\
\hline \multirow[t]{23}{*}{ Pleocyemata } & Caridea & Alpheidae (2) & Alpheus packardii Kingsley, 1880 & 101 & 2 \\
\hline & & & Alpheus aff. floridanus Kingsley, 1878* & 3 & 2 \\
\hline & & & Alpheus sp. (juvenile) & 3 & \\
\hline & & Hippolytidae (3) & Hippolyte obliquimanus Dana, 1852 & 180 & \\
\hline & & & Latreutes parvulus (Stimpson, 1871)* & 174 & \\
\hline & & & Thor manningi Chace, 1972 & 17 & \\
\hline & & Processidae (1) & Processa fimbriata Manning \& Chace, 1971* & 3 & \\
\hline & & Palaemonidae (2) & Leander tenuicornis (Say, 1818) & 10 & \\
\hline & & & Cuapetes americanus (Kingsley, 1878) & 10 & \\
\hline & & Sergestidae (1) & Unidentified* & 1 & \\
\hline & Anomura & Diogenidae (2) & Clibanarius antillensis (Stimpson, 1859)* & & 3 \\
\hline & & & Clibanarius sclopetarius (Herbst, 1796)* & & 1 \\
\hline & & & Clibanarius sp. (juvenile) & 1 & 2 \\
\hline & & Paguridae (1) & Pagurus brevidactylus (Stimpson, 1859) & 6 & \\
\hline & Brachyura & Portunidae (3) & Achelous tumidulus Stimpson, 1871* & 2 & \\
\hline & & & Cronius sp. & 1 & \\
\hline & & & Callinectes sp. & 1 & \\
\hline & & Panopeidae (1) & Panopeus occidentalis Saussure, 1857* & 3 & 4 \\
\hline & & & Panopeus sp. (juvenile) & & 1 \\
\hline & & Epialtidae (1) & Chorinus heros (Herbst, 1790)* & 1 & \\
\hline & & Majidae (1) & Omalacantha bicornuta (Latreille, 1825) & & 1 \\
\hline & Achelata & Palinuridae (1) & Panulirus argus (postlarvae) (Latreille, 1804) & 1 & 2 \\
\hline & & & Total number of species per sampling site & 19 & 10 \\
\hline
\end{tabular}


Tab. II. Ranking of species cumulative contributions to dissimilarity, in the Paraguaná Peninsula, Venezuela (*, statistically different).

\begin{tabular}{|c|c|c|c|c|c|c|}
\hline Species & Mean & SD & Ratio & Cumulative sum & $\mathrm{P}$ & \\
\hline L. parvulus & 0.316199 & 0.055269 & 57211 & 0.3233 & 0.004 & $* *$ \\
\hline H. obliquimanus & 0.314173 & 0.051399 & 61125 & 0.6445 & 0.004 & $* *$ \\
\hline A. packardii & 0.161391 & 0.040321 & 40027 & 0.8095 & 0.004 & $* *$ \\
\hline P. schmitti & 0.048169 & 0.047205 & 10204 & 0.8588 & 1000 & \\
\hline T. manningi & 0.032165 & 0.029431 & 10929 & 0.8917 & 0.004 & $* *$ \\
\hline L. tenuicornis & 0.022105 & 0.028063 & 0.7877 & 0.9143 & 0.004 & $* *$ \\
\hline C. americanus & 0.018567 & 0.013723 & 13530 & 0.9333 & 0.004 & $* *$ \\
\hline P. occidentalis & 0.008636 & 0.009026 & 0.9568 & 0.9421 & 1000 & \\
\hline P. brevidactylus & 0.007857 & 0.010033 & 0.7831 & 0.9501 & 0.004 & $* *$ \\
\hline A. aff. floridanus & 0.007688 & 0.009483 & 0.8107 & 0.9580 & 1000 & \\
\hline C. antillensis & 0.006307 & 0.009841 & 0.6409 & 0.9644 & 1000 & \\
\hline P. argus & 0.005063 & 0.009722 & 0.5207 & 0.9696 & 1000 & \\
\hline P. fimbriata & 0.004824 & 0.009849 & 0.4898 & 0.9745 & 0.004 & $* *$ \\
\hline P. cf. brasiliensis & 0.004273 & 0.009696 & 0.4407 & 0.9789 & 1000 & \\
\hline C. heros & 0.003750 & 0.007661 & 0.4895 & 0.9827 & 0.004 & $* *$ \\
\hline Metapeneopsis sp. & 0.003750 & 0.007661 & 0.4895 & 0.9866 & 0.004 & $* *$ \\
\hline A. tumidulus & 0.003421 & 0.006984 & 0.4899 & 0.9901 & 0.004 & $* *$ \\
\hline$P$. cf. duorarum & 0.003099 & 0.005129 & 0.6043 & 0.9932 & 1000 & \\
\hline O. bicornuta & 0.002192 & 0.005000 & 0.4385 & 0.9955 & 1000 & \\
\hline C. sclopetarius & 0.002136 & 0.004848 & 0.4407 & 0.9977 & 1000 & \\
\hline Cronius sp. & 0.001140 & 0.002328 & 0.4899 & 0.9988 & 0.004 & $* *$ \\
\hline Callinectes sp. & 0.001140 & 0.002328 & 0.4899 & 1.0000 & 0.004 & $* *$ \\
\hline
\end{tabular}

\section{DISCUSSION}

In the Caribbean area, the most abundant decapods are usually carideans belonging to the family Hyppolytidae, within the genera Hippolyte, Latreutes, Tozeuma and Thor (HeCK, 1979; Lewis, 1984; BAUER, 1985a,b; Holmquist et al., 1989; De Grave et al., 2006; Aguirre-Aguirre et al., 2007). Our results partially agree with these reports: individuals in the genera Latreutes and Hippolyte accounted for $67 \%$ of the total individuals for the El Supí locality. However, in Adícora, the species Penaeus schmitti (Penaeidae family) contributed to almost $60 \%$ of the decapod community.

Of the 23 decapod species reported here, eight are new records for the Falcón state: Achelous tumidulus Stimpson, 1871, Alpheus floridanus Kingsley, 1878, Chorinus heros (Herbst, 1790), Clibanarius antillensis (Stimpson, 1859), Clibanarius sclopetarius (Herbst, 1796), Latreutes parvulus (Stimpson, 1866), Panopeus occidentalis Saussure, 1857, and Processa fimbriata Manning \& Chace, 1971. These records represent habitat extensions and fill gaps in the geographical distribution of the species along the northern coast of South America. Four of these species were known to occur offshore in some of the Venezuelan Leeward Antilles, but not in the mainland coast, these are: A. tumidulus, $C$. heros, L. parvulus and P. fimbriata. Thus, our results expand their distribution to the continental portion of the Venezuelan territory (Appendix 1).

The species richness found in our study was equal or higher with respect to that described for similar seagrass communities, even though this comparison is constrained because the sampling methods are not standardized (HECK, 1979). For example, at Apalachee Bay (Florida, U.S.A.,

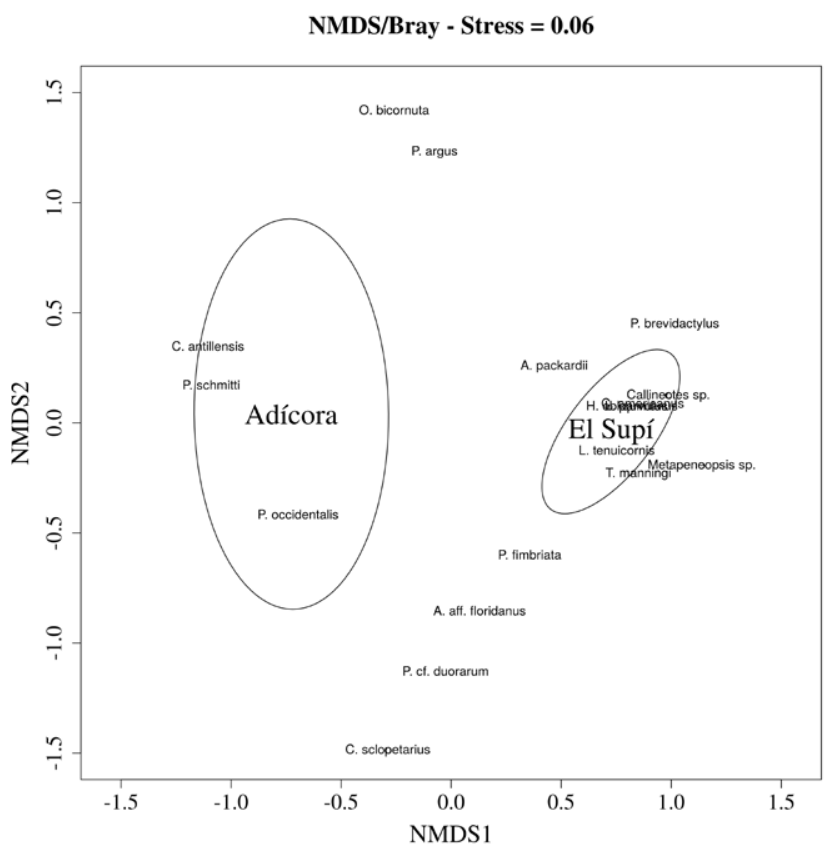

Fig. 2. Non-metric multidimensional scaling ordination (NMDS) for the abundance of decapods associated with two mixed seagrass meadows seagrass meadows at the Paraguaná Peninsula, Falcón State, Venezuela.

Gulf of Mexico), 19 species of decapods have been reported in association with Thalassia testudinum (LewIs, 1984). However, samplings in that survey were done through coring devices, which is a more efficient method to capture organisms of slow movement and smaller size (e.g. peracarids) (LewIS \& STONER, 1983). At Morrocoy National Park, a locality 
Tab. III. Seagrass meadow characteristics and environmental parameters by sampling site, Paraguaná Peninsula, Venezuela.

\begin{tabular}{lcc} 
& Adícora & El Supí \\
\hline Area of meadow $\left(\mathrm{m}^{2}\right)$ & 1442 & 5860 \\
Leaf length $(\mathrm{cm})($ Mean $\pm \mathrm{SE})$ & $12.93 \pm 0.07$ & $13.12 \pm 0.10$ \\
Leaf width $(\mathrm{cm})($ Mean $\pm \mathrm{SE})$ & $1.03 \pm 0.00$ & $1.05 \pm 0.01$ \\
Stem density $\left(\mathrm{stem} / \mathrm{m}^{2}\right)$ & 908.89 & 1511.48 \\
Mean LAI $\left(\mathrm{m}^{2} / \mathrm{m}^{2}\right)$ & 1.23 & 2.18 \\
Substrate & Sandy calcareous sediment & Sandy calcareous sediment with coral boulders $($ Porites sp.) \\
Temperature $\left({ }^{\circ} \mathrm{C}\right)(\mathrm{Mean} \pm \mathrm{SE})$ & $27.40 \pm 0.00$ & $28.37 \pm 0.03$ \\
Salinity $(\%)(\mathrm{Mean} \pm \mathrm{SE})$ & $35.66 \pm 0.33$ & $37.00 \pm 0.00$ \\
Dissolved oxygen $(\mathrm{mg} / \mathrm{l})(\mathrm{Mean} \pm \mathrm{SE})$ & $6.76 \pm 0.07$ & $6.18 \pm 0.01$ \\
$\mathrm{pH}($ Mean $\pm \mathrm{SE})$ & $8.48 \pm 0.09$ & $8.54 \pm 0.02$ \\
\hline
\end{tabular}

closer to our study area, the reported richness was of 10 decapod species (RoDRíGUEZ \& VILlamizar, 2000), three of which were also present in our sampling sites: Alpheus packardii, Pagurus sp. and Leander tenuicornis (Say, 1818). Noteworthy, taxa not recorded at El Supí nor Adícora, in comparison with Morrocoy National Park, are the infaunal families Callianassidae and Upogebiidae; such differences are attributed to the sampling method using coring devices (Rodríguez \& Villamizar, 2000).

Push net samplings, similar to the one we used, have found richness of 23 species in Puerto Rico (BAUER, 1985a,b) and of 14 species in Honduras (DE Grave et al., 2006). In both of these sites, the most abundant species was Latreutes fucorum (Fabricius, 1798) (Hippolytidae) (BAUER, 1985a,b; De Grave et al., 2006). In our study, the dominant species include Hippolyte obliquimanus and Latreutes parvulus (Hippolytidae). Equivalent samplings in the nearby Colombian Guajira Peninsula have yielded a richness of 23 decapods, the most frequent species being Tozeuma carolinense Kingsley, 1878 (Hippolytidae) (AguirRe-AguirRe et al., 2007), which is considered one of the most common invertebrates in the epifauna of the western Atlantic (HECK, 1979; GREENING \& LIVINGSTON, 1982). This latter species was notably absent from our study site; however, it has been proposed that other small-sized and morphologically similar species within Hyppolytidae, such as Thor manningi Chace, 1972, may be ecologically equivalent to T. carolinense in some habitats (BAUER, 1985a). In Venezuela, comparable push net methods have been used to survey caridean shrimps associated with $T$. testudinum meadows at Los Roques Archipelago National Park, recording 24 species (22 Caridea, 2 Dendrobranchiata; B. López-Sánchez, unpubl. data). Among these species, seven were also present in the Paraguaná Peninsula: Cuapetes americanus, Leander tenuicornis, Alpheus packardii, A. floridanus, T. manningi, H. obliquimanus, and Processa fimbriata.

The density of individuals found in our study was inferior to that reported for Puerto Rico (BAUER, 1985a) and Florida (GoRE et al., 1981). Conversely, our results show similar densities to those encountered in T. testudinum meadows from Los Roques Archipelago (7.66 $\pm 0.78 \mathrm{ind} /$ $\mathrm{m}^{2}$ ) (B. López-Sánchez, unpubl. data). The seagrass beds in Los Roques are highly similar to those of Paraguaná, as they both lay on a sandy calcareous substrate and are fringed by coral reefs offshore (B. López-Sánchez, pers. comm.).
In addition, in Los Roques and in the Paraguaná Peninsula, the influx of freshwater into the sampling sites is only by rainfall (López et al., 2011), unlike the meadows of Puerto Rico for example, where juveniles of two freshwater genera have been found (i.e. Atya Leach, 1816 and Xiphocaris von Martens, 1872) (BAUER, 1985a). It is likely that such freshwater influx, that constitutes an input of nutrients, promotes higher decapod abundances in Puerto Rico with respect to these sites in Venezuela, which can be considered atypically arid; nonetheless, it would be interesting to evaluate these environments during the rainy season.

A particular feature of the species composition at the Adícora locality is the occurrence of penaeid shrimps. Penaeus schmitti, commonly known as the white shrimp, has rarely been recorded in association with similar beds in other surveys, where the Dendrobranchiata genera typically present are Sicyonia, Metapenaeopsis, and the species Penaeus duorarum Burkenroad, 1939 (Heck, 1979; Lewis, 1984; Aguirre-Aguirre et al., 2007). Penaeus schmitti is considered the most abundant and economically valuable penaeid in Venezuela, forming an essential element in the artisanal and industrial fisheries of the Venezuelan Atlantic, including Lake Maracaibo and the Gulf of Venezuela (SARPA, 1996; Alió, 2000), which are adjacent to the Paraguaná Peninsula region. It has been suggested that the recruits of $P$. schmitti that spawn in the Gulf of Venezuela usually migrate to coastal zones during their final larval stages, and that their most intense reproductive period is the second quarter of the year (EwALD, 1964, 1965); which coincides with our sampling dates and may explain the occurrence of large numbers of $P$. schmitti juveniles within the Adícora meadow.

Another important species for the fisheries industries in Venezuela is the spiny lobster Panulirus argus (Latreille, 1804) (MarCANO \& Bolaños, 2001). According to the IUCN red list of endangered species, $P$. argus has been classified as Insufficient Data (BuTLER et al., 2009). The presence of this species in its postlarval stage at both sampling sites, together with caridean larvae at El Supí and juvenile Penaeus schmitti at Adícora, highlights the importance of seagrass meadows as nursery habitats. Furthermore, the simultaneous occurrence of caridean larvae and P. argus at El Supí may suggest that they play a role in the pollination of the meadow, since their presence in the area coincided with its flowering 
period; however, members of this latter superfamily are yet to be confirmed as pollinators of T. testudinum (TUSSENBROEK et al., 2016). Altogether, this information should serve to motivate conservation actions of these habitats along the western Venezuelan coast, as well as to prioritize research and monitoring efforts.

Regarding the characteristics of the T. testudinum meadows, the short-shoot stem density at both sampling sites was comparatively high with respect to values previously reported for the Caribbean. This was more evident at El Supí, where it was even higher $\left(1511.48 \mathrm{stem} / \mathrm{m}^{2}\right)$ than the previously reported values $\left(\sim 1275 \mathrm{stem} / \mathrm{m}^{2}\right.$; LinTON \& FISHER, 2004). Plant density is considered a good indicator of the state of marine beds, elevated densities corresponding with healthier meadows (LiNTON \& FisHER, 2004); thus, our results strongly suggest that the meadows at Paraguaná were in good physical condition during our sampling period. A further general indicator of the health of a meadow is the LAI, which takes into account the photosynthetic productive portion of the seagrass leaves as well as the short-shoot stem density (LinTon \& Fisher, 2004). For both of our sampling localities, the LAI was within the reference values for Thalassia spp. beds in the Caribbean (ranging from 0.03 to 8.7; LINTON \& FisHER, 2004); the higher values of LAI for El Supí being related to wider and longer leaves, and also reflecting the higher short-shoot stem density at that site.

In our study, the localities were distinguished by a NMDS analysis, indicating dissimilarities in abundance and species composition. Particularly, the meadow at El Supí showed the highest values of short-shoot stem density, mean LAI, vegetation cover, and total area. In addition, other qualitative aspects of El Supí were notable, such as the presence of T. testudinum flowers, several macroalgae species, and dispersed coral boulders; none of which were observed at Adícora. Both findings may suggest that El Supí is an environment with a greater structural complexity, as it has been shown that the structure and shape of macrophytes increases habitat complexity, enhances settlement, provides shelter, and reduces water flow for the benthic community (Heck \& Wetstone, 1977; Stoner \& Lewis, 1985; CAstel et al., 1989). This highly heterogeneous environment and the greater area occupied by the meadow should provide additional niches for numerous species (HECK \& WETSTONE, 1977), and may explain the greater abundance and more diverse species composition that was evident at El Supí. It should also be taken into account that, within Falcón state, the beaches at Adícora are the ones most visited by tourists (CAZORla et al., 2010), but the consequences on the benthic ecosystem have not yet been evaluated. Further detailed studies -including comparisons between seasons and among other sites-are needed to clarify which of these hypotheses is more likely to explain the differences in the abundance and richness of decapods associated with T. testudinum beds in the Paraguaná Peninsula.

Our study is one of the few surveys of the decapod community of the Paraguaná Peninsula with an ecological approach. Based on our results and on the most recent literature for this zone (i.e. SÁNCHEZ et al., 1994; CARMONASuÁrez \& CONDE, 1996), we may infer that the seagrass meadows in the area reflect an overall good health, and that they may represent critical habitats for the establishment and development of diverse marine crustacean populations, especially for the juvenile stages of commercially valuable species. These findings should serve to assist policy makers about the importance of non-protected areas that could be monitored more frequently, given that they are likely to serve as nursery habitats for species of economical profit.

Acknowledgements. This research was supported by the Venezuelan Institute for Scientific Research (IVIC) project \#467. We express our gratitude to Adriana Oliveiras for her assistance during fieldwork, and to Marcial Quiroga for drafting the map in Figure 1. We thank Dr. Wilmer Rojas (IVIC) for his kind help in the laboratory, and M.Sc. Jonathan VeraCaripe (UCV) for confirming the identity of the species. We also thank the two anonymous reviewers whose suggestions helped to improve this manuscript.

\section{REFERENCES}

Abele, L. \& Kim, W. 1986. An illustrated guide to the marine decapod crustaceans of Florida. Tallahassee, Department of Environmental Regulation. 196p.

Aguirre-Aguirre, A.; Duque, G. \& Gómez-López, D. I. 2007. Caracterización de la fauna de macroinvertebrados epibentónicos asociados a praderas de Thalassia testudinum (Banks ex König, 1805) en La Guajira, Caribe colombiano. Gulf and Caribbean Fisheries Institute 58:56-61.

Alıó, J. 2000. Los recursos vivos del sistema de Maracaibo. In: RoDRíGUEz, G. ed. EI Sistema de Maracaibo, 2nd ed. Caracas, Instituto Venezolano de Investigaciones Científicas, p. 163-173.

Ávila, E.; YÁÑEz, B. \& VÁzQUEZ-MaLdonado, L. E. 2015. Influence of habitat structure and environmental regime on spatial distribution patterns of macroinvertebrate assemblages associated with seagrass beds in a southern Gulf of Mexico coastal lagoon. Marine Biology Research 11(7):1-10.

BAUER, R. T. 1985a. Diel and seasonal variation in species composition and abundance of caridean shrimps (Crustacea, Decapoda) from seagrass meadows on the north coast of Puerto Rico. Bulletin of Marine Science 36(1):150-162.

BAUER, R. T. 1985b. Penaeoid shrimp fauna from tropical seagrass meadows: species composition, diurnal, and seasonal variation in abundance. Proceedings of the Biological Society of Washington 98(1):177-190.

BAUER, R.T. 1985c. Hermit crab fauna from sea grass meadows in Puerto Rico: Species composition, diel and seasonal variation in abundance. Journal of Crustacean Biology 5(2):249-257

Bitter-Soto, R. 1999. Benthic communities associated to Thalassia testudinum (Hydrocharitaceae) at three localities of Morrocoy National Park, Venezuela. Revista de Biologia Tropical 47(3):443-451.

Bostrom, C. \& BonsdorfF, E. 2000. Zoobenthic community establishment and habitat complexity - The importance of seagrass shoot-density, morphology and physical disturbance for faunal recruitment. Marine Ecology Progress Series 205:123-138.

Butler, M.; Cockcroft, A.; MacDiarmid, A. \& Wahle, R. 2009. Panulirus argus. The IUCN Red List of Threatened Species 2011. Version 2011.1 Available at <http://www.iucnredlist.org/details/169976/0>. Accessed on 17 April 2017.

Cabaço, S.; Santos, R. \& Duarte, C. M. 2008. The impact of sediment burial and erosion on seagrasses: a review. Estuarine, Coastal and Shelf Science 79(3):354-366.

Carmona, C. \& Conde, J. E. 1989. Caracterización de las costas del estado Falcón, Venezuela. Boletín Del Instituto Oceanográfico de Venezuela 28(1,2):127-133.

Carmona-Suárez, C. A. 2000. Difference between Mithraculus spp. communities in exposed and sheltered shallow-water Thalassia beds in Venezuela. Crustacean Issues 12:419-430. 
Carmona-Suárez, C. A. 2007. Spatial distribution, density, and relative growth of Microphrys bicornutus (Latreille, 1826) (Brachyura: Majidae) in five biotopes in a Thalassia complex. Scientia Marina 71(1):5-14.

Carmona-Suárez, C. A. \& Conde, J. E. 1996. Littoral brachyuran crabs (Crustacea: Decapoda) from Falcón, Venezuela, with biogeographical and ecological remarks. Revista Brasileira De Biologia 56(4):725-747.

Casares, F. A. \& Creed, J. C. 2008. Do small seagrasses enhance density, richness, and diversity of macrofauna? Journal of Coastal Research:790-797.

Castel, J.; Labourg, P. J.; Escaravage, V.; Auby, I. \& Garcia, M.E. 1989. Influence of seagrass beds and oyster parks on the abundance and biomass patterns of meio- and macrobenthos in tidal flats. Estuarine, Coastal and Shelf Science 28(1):71-85.

Cazorla, D; Loyo., J; Lugo, L. \& Acosta, M. 2010. Aspectos clínicos, epidemiológicos y de tratamiento de cinco casos de envenenamiento por erizos de mar en Adícora, península de Paraguaná, estado Falcón, Venezuela. Boletín de Malariología y Salud Ambiental 50(1):127-133.

CHACE, F. A. JR. 1972. The shrimps of the Smithsonian-Bredin Caribbean expeditions with a summary of the West Indian shallow-water species (Crustacea: Decapoda: Natantia). Smithsonian Contributions to Zoology 98:1-179.

Chiussi, R.; Díaz, H.; RitTsChOF, D. \& Forward JR., R. B. 2001. Orientation of the hermit crab Clibanarius antillensis: effects of visual and chemical cues. Journal of Crustacean Biology 21(3):593-605.

Christoffersen, M. L. 1998. Malacostraca. Eucarida. Caridea. Crangonoidea and Alpheoidea (Except Glyphocrangonidae and Crangonidae). Catalogue of Crustacea of Brazil. Rio de Janeiro, Museu Nacional, p. 351-372.

De Grave, S.; Livingston, D. \& Speight, M. R. 2006. Diel variation in sea grass dwelling shrimp: when to sample at night? Journal of the Marine Biological Association of the United Kingdom 86(06):1421-1422.

EWALD, J. J. 1964. La biología y pesquería del camarón en la zona Occidental. Primer Informe Anual. Caracas, IVIC/FONAIAP. 29p.

EWALD, J. J. 1965. Investigaciones sobre la biología del camarón comercial en el Occidente de Venezuela. Segundo Informe Anual. IVIC/FONAIAP: Caracas, Venezuela. 36p.

GodDARD, D. \& Picard, X. 1976. Geomorfología y sedimentación en la costa del estado Falcón, cabo San Román a Chichiriviche. Memoria II Congreso Latinoamericano de Geología, Tomo II. Boletín de Geología, Publicación Especial, Caracas 7:1157-1180.

Gore, R. H.; Gallaher, E. E.; Scotto, L. E. \& Wilson, K. A. 1981. Studies on decapod Crustacea from the Indian River Region of Florida: XI. Community composition, structure, biomass and species-areal relationships of seagrass and drift algae-associated macrocrustaceans. Estuarine, Coastal and Shelf Science 12(4):485IN1-508.

Greening, H. S. \& Livingston, R. J. 1982. Diel variation in the structure of seagrass-associated epibenthic macroinvertebrate communities. Marine Ecology Progress Series 7:147-156.

Hazlett, B. A. 1966. Social behavior of the Paguridae and Diogenidae of Curaçao. Studies on fauna of Curaçao and other Caribbean Islands 23:1-143.

Heck, K. L. JR. \& WeinsteIn, M. P. 1989. Feeding habits of juvenile reef fishes associated with Panamanian seagrass meadows. Bulletin of Marine Science 45(3):629-636.

Heck, K. L. JR. \& Wetstone, G. S. 1977. Habitat complexity and invertebrate species richness and abundance in tropical seagrass meadows. Journal of Biogeography 4:135-142.

HECK, K. L. J. 1979. Some determinants of the composition and abundance of motile macroinvertebrate species in tropical and temperate turtlegrass (Thalassia testudinum) meadows. Journal of Biogeography 6(2): 183200.

HernándeZ- Ávila, I.; Gómez, A.; Lira, C. \& Galindo, L. 2007. Benthic decapod crustaceans (Crustacea: Decapoda) of Cubagua Island, Venezuela. Zootaxa 1557:33-45.

Holmquist, J. G.; Powell, G. V. N. \& Sogard, S. M. 1989. Decapod and stomatopod assemblages on a system of seagrass-covered mud banks in Florida Bay. Marine Biology 100(4):473-483.

Jiménez, M.; Bone, D.; Pereira, G. \& Liñero, I. 2005. Comunidad de moluscos bivalvos en una pradera de Thalassia testudinum en el Golfo de Cariaco, estado Sucre, Venezuela. Boletin del Instituto Oceanografico de Venezuela 44(1):41-50.
LEWIS III, G. F. \& STONER, A. W. 1983. Distribution of macrofauna within seagrass beds: an explanation for patterns of abundance. Bulletin of Marine Science 33(2):296-304

LEWIS, F. 1984. Distribution of macrobenthic crustaceans associated with Thalassia, Halodule and bare sand substrata. Marine Ecology Progress Series 19(1967): 101-113.

LinTON, D. \& FisheR, T. 2004. CARICOMP Caribbean Coastal Marine Productivity Program 1993-2003. Kingston, Caricomp. 92p.

López, B.; Barreto, M. B. \& Conde, J. E. 2011. Caracterización de los manglares de zonas semiáridas en el noroccidente de Venezuela. Interciencia 36(12):888-893.

MANNING, R. B. 1975. Two methods for collecting decapods in shallow water. Crustaceana 29(3):317-319.

Manning, R. B. \& Chace, F. A. 1971. Shrimps of the family Processidae from the Northwestern Atlantic Ocean (Crustacea: Decapoda: Caridea). Smithsonian Contributions to Zoology 89:1-41.

Marcano, J. \& Bolaños, J.. 2001. Cangrejos májidos (Decapoda: Brachyura: Majidae) de las aguas someras marinas venezolanas. Boletín del Instituto Oceanográfico de Venezuela 40:71-82.

Martínez-Iglesias, J. C.; Carvacho, A. \& Ríos, R. 1996. Catálogo de los carídeos marinos (Crustacea, Decapoda, Caridea) de las aguas someras de Cuba. Avicennia 4/5:27-40.

Melo, G. A. S. 1999. Manual de identificação dos Crustacea Decapoda do litoral brasileiro: Anomura, Thalassinidea, Palinuridea, Astacidae. São Paulo, Editora Plêiade. 551p.

Miloslavich, P.; Klein, E.; Martin, A.; Bastidas, C.; Marin, B. \& Spiniello, P. 2005. Venezuela. In: Miloslavich, P. \& Klein, E. eds. Caribbean Marine Biodiversity: the Known and the Unknown. Caracas, Universidad Simón Bolívar, Departamento de Estudios Ambientales and INTECMAR, p. 109-136.

Oksanen, J.; Blanchet, F. G.; Friendly, M.; Kindt, R.; Legendre, P.; McGlinn, D.; Minchin, P. R.; O’Hara, R. B.; Simpson, G. L.; Solymos, P.; Stevens, M. H. H.; Szoecs, E. \& Wagner, H. 2017. Vegan: Community Ecology Package. R package version 2.4-4. Available at $<$ https://CRAN.R-project.org/package=vegan $>$.

Pereira, G.; Gárcia, J. V. \& CAPelo, J. C. 2004. Crustáceos decápodos del bajo delta del río Orinoco: Biodiversidad y estructura comunitaria. Evaluación rápida de la biodiversidad y aspectos sociales de los ecosistemas acuáticos del delta del río Orinoco y Golfo de Paria, Venezuela. Washington, D. C. Boletın RAP de Evaluación Biológica 37:61-69.

P érez-Farfante, I. \& Kensley, B. 1997. Penaeids and Sergestoid Shrimps and Prawns of the World: Keys and Diagnoses for the Families and Genera. Paris, Mémoires du Muséum National d'Histoire Naturelle 175. $233 \mathrm{p}$.

PIÑango, H. 1988. Contribución al conocimiento de los Pagúridos (Crustacea: Decapoda: Anomura) litorales de Venezuela. Honours dissertation. Facultad de Ciencias, Universidad Central de Venezuela. 202p.

R Core Team. 2017. R: A language and environment for statistical computing. R Vienna, Foundation for Statistical Computing. Available at $<$ https://www.R-project.org/>.

Rodríguez, C. \& Villamizar, E. 2000. Fauna bentónica asociada a Thalassia testudinum (Hydrocharitaceae) en el Parque Nacional Morrocoy, Venezuela. Revista de Biología Tropical 48(1):243-249.

RodríGuez, G. 1980. Los crustáceos decápodos de Venezuela. Caracas, Instituto Venezolano de Investigaciones Científicas. 494p.

Rodríguez-Almaraz, G.; Leija-Tristán, A. \& Mendoza, R. 2000. Records of caridean shrimps (Crustacea: Decapoda) from the coasts of the Mexican Pacific Ocean, Gulf of Mexico and Mexican Caribbean. Bulletin of Marine Science 67:857-867.

SÁnchez, R.; Álvarez, S. \& Carmona-SuÁrez, C. A. 1994. Inventario de los crustáceos decápodos, (Infraorden Penaeidea y Caridea) del estado Falcón, Venezuela. Acta Científica Venezolana 45:218-225.

SARPA. 1996. Estadísticas del Subsector Pesquero y Acuícola de Venezuela, 1990- 1995. Caracas, Servicio Autónomo de los Recursos Pesqueros y Acuícolas Ministerio de Agricultura y Cría. 74p.

Short, F. T. \& NeCKLES, H. A. 1999. The effects of global climate change on seagrasses. Aquatic Botany 63:169-196.

SHORT, F. T. \& WYLLIE-ECHEVERRIA, S. 1996. Natural and human-induced disturbance of seagrasses. Environmental Conservation 23(1):17-27.

Short, F. T.; Coles, R. G. \& Pergent-Martini, C. 2001. Global seagrass distribution. In: Global seagrass research methods. Amsterdam, Elsevier Science B. V., p. 5-30 
Short, F.; Carruthers, T.; Dennison, W. \& Waycott, M. 2007. Global seagrass distribution and diversity: a bioregional model. Journal of Experimental Marine Biology and Ecology 350(1-2):3-20.

Sogard, S. M. 1989. Colonization of artificial seagrass by fishes and decapod crustaceans: importance of proximity to natural eelgrass. Journal of Experimental Marine Biology and Ecology 133(12):15-37.

StOner, A. W. \& Lewis, F. G. 1985. The influence of quantitative and qualitative aspects of habitat complexity in tropical sea-grass meadows. Journal of Experimental Marine Biology and Ecology 94(1-3):19-40.

Tagliafico, A.; Gassman, J.; Fajardo, C.; Marcano, Z.; Lira, C. \& Bolaños, J. 2005. Decapod crustaceans inventory of La Pecha Island, archipelago Los Frailes, Venezuela. Nauplius 13(1):89-94.

Thayer, G. W.; BJorndal, K. A.; Ogden, J. C.; Williams, S. L. \& Zieman, J. C. 1984. Role of larger herbivores in seagrass communities. Estuaries 7(4): 351-376.
Tussenbroek, B. I. van; Villamil, N.; Márquez-Guzmán, J.; Wong, R.; Monroy-Velázquez; L. \& Solis-Weiss V. 2016. Experimental evidence of pollination in marine flowers by invertebrate fauna. Nature Communications 7:12980.

WiLliams, A. B. 1984. Shrimps, lobsters, and crabs of the Atlantic coast of the Eastern United States, Maine to Florida. Washington, D. C., Smithsonian Institution Press. 752p.

Yamada, K.; Hori, M.; TanaKa, Y.; Hasegawa, N. \& NaKaoka, M. 2007. Temporal and spatial macrofaunal community changes along a salinity gradient in seagrass meadows of Akkeshi-ko estuary and Akkeshi Bay, northern Japan. Hydrobiologia 592(1):345-358.

ZuPO, V. \& NelsON, W. G. 1999. Factors influencing the association patterns of Hippolyte zostericola and Palaemonetes intermedius (Decapoda: Natantia) with seagrasses of the Indian River Lagoon, Florida. Marine Biology 134(1):181-190.

Appendix 1. Taxonomic summary of the new records for Falcón state, considering diagnosis, examined material, measurements, broad geographical distribution, and distribution in Venezuela. Depending on the species, measurements were taken for the following features: CL, length of carapace; SL, length of anterior shield of carapace; $\mathrm{CW}$, width of carapace. When more than one specimen was examined, we give measurements of minimum and maximum for the respective feature.

\section{Achelous tumidulus Stimpson, 1871}

Diagnosis. Two spines on palm; row of spinules but no spine on posterodistal margin of merus of each swimming leg. Movable part of antenna excluded from orbit by prolongation of basal segment; anterolateral teeth of carapace, alternatively large and small (ABELE \& KIM, 1986).

Material examined. CCDGR.- 1 juvenile; 20 .

Measurements. CW: juvenile $8.58 \mathrm{~mm}$; $\widehat{0} 16.10-16.85 \mathrm{~mm}$. CL: $6.38 \mathrm{~mm}$; o $11.30-11.50 \mathrm{~mm}$.

Habitat. Sandy intertidal bottoms (HeRnANDEz-Ávila et al., 2007). Now in seagrass meadows.

General distribution. Western Atlantic. From Bermuda to Santa Catarina, Brazil; including Florida, the Gulf of Mexico, the Antilles, and the Guyanas (RodríGuez, 1980; Melo, 1999).

Distribution in Venezuela. Cubagua Island (HernandEZ-Ávila et al., 2007). Now in Paraguaná Peninsula, Falcón state.

Alpheus aff. floridanus Kingsley, 1878

Diagnosis. Rostrum dorsally subcarinate. Ocular hoods not spined and messially delimited by adrostral depressions. Antennal scale without prominent tooth of lateral margin. Major first chela with dorsal and ventral margins entire, not notched. Proximal article of carpus of the second periopod shorter than second; merus of third and fourth periopods with distal end of flexor margin rectangular, not produced into prominent tooth; dactyls of the third and fourth periopods subspatulate (CHACE, 1972).

Material examined. CCDGR.- + ; $\widehat{\partial}$.

Measurements. CL: + $9.90 \mathrm{~mm}$; $11.99 \mathrm{~mm}$.

Habitat. Mud or sandy muddy bottoms up to $37 \mathrm{~m}$ depth, in conch shells Lobatus gigas (Linnaeus, 1758), and on seagrass beds (RoDríGUEZ, 1980).

General distribution. Tropical Atlantic. From the Gulf of Mexico to Bahia, Brazil, in the Western Atlantic; and from Guinea to Congo, in the Eastern Atlantic (RoDRíGUEZ, 1980).

Distribution in Venezuela. Los Roques National Park (B. López-Sánchez, unpubl. data). Now in Paraguaná Peninsula, Falcón state.

\section{Chorinus heros (Herbst, 1790)}

Diagnosis. Oval carapace, three times longer than rostrum. Rostrum divided from the base into two strong and long horns, approximately $1 / 3$ of the carapace length, provided of two rows of hairs on the inner margin. Preorbital spine directed anteriorly, approximately $1 / 3$ of the length of rostral horns. First pair of walking legs much longer than remaining pairs. The anterior third of the dorsal surface of the carapace with short tubercles provided with setae brushes (RODRíGUEZ, 1980).

Material examined. CCDGR.- 0 .

Measurements. CW: $39.50 \mathrm{~mm}$. CL: $18.70 \mathrm{~mm}$.

Habitat. Between rocks in shallow water, up to $20 \mathrm{~m}$ depth (MARCANO \& Bolaños, 2001). Now on seagrass beds.General distribution. Western Atlantic. From Bermuda to Bahia, Brazil; including Florida Keys, the Gulf of Mexico, the Antilles, and Venezuela (Rodríguez, 1980; Melo, 1999).

Distribution in Venezuela. Cubagua and Margarita Islands (MARCANo \& Bolaños, 2001). Now in Paraguaná Peninsula, Falcón state.

\section{Clibanarius antillensis (Stimpson, 1859)}

Diagnosis. Dactyls of walking legs shorter than propodus. Dactyls and propodus with broad longitudinal light stripe on dark background (olive green to brown color). Dense pubescence in the posterior margin of carapace and telson. Telson almost straight or slightly rounded, with no evident calcareous spines (PIÑANGo, 1988).

Material examined. CCDGR.- 1 juvenile; 1 ovigerous $\stackrel{\circ}{\text {; }} \widehat{\widehat{\partial}}$.

Measurements. SL: ovig. $\bigcirc 3.74 \mathrm{~mm}$; $3.30 \mathrm{~mm}$.

Habitat. On sandy bottoms, near and on Thalassia testudinum beds, and on Arca zebra banks (RoDRíGuez, 1980).

General distribution. Western Atlantic. From southern Florida to Brazil (RodRÍGUEZ, 1980); including Puerto Rico (BAUER, 1985c), and Curaçao (HazLeTt, 1966).

Distribution in Venezuela. Cubagua Island (HeRnANDEZ- Ávila et al., 2007), and Mochima National Park (CHIUssi et al., 2001). Now in Paraguaná Peninsula, Falcón state.

\section{Clibanarius sclopetarius (Herbst, 1796)}

Diagnosis. Dactyls of walking legs -second and third- of similar length or slightly longer than propodus, never shorter. Dactyls and propodus of the second and third pereiopods with dark (olive green to brown color) stripe laterally, bordered on each side by light stripe of equal thickness (PiÑango, 1988; RodríGueZ, 1980).

Material examined. CCDGR.- $\hat{0}$.

Measurements. SL: $5.00 \mathrm{~mm}$.

Habitat. Sandy bottoms (RoDRÍGUEZ, 1980). Now on seagrass beds.

General distribution. Western Atlantic. From Florida to Santa Catarina, Brazil; including the Antilles, Venezuela and Guyana (Rodríguez, 1980; Melo, 1999). 
Distribution in Venezuela. Zapara Island, and Tacarigua Lagoon National Park (Rodríguez, 1980). Now in Paraguaná Peninsula, Falcón state.

\section{Latreutes parvulus (Stimpson, 1866)}

Diagnosis. Rostrum laterally compressed, almost circular in female, more elongate in male, upper margin with 6-8 teeth in female, $2-3$ in male; few small teeth on tip; lower margin unarmed or with up to 5 shallow teeth, ventral part of rostrum produced somewhat backward. Caparace with middorsal row of 5-7 small, erect teeth; making an angle at base of mid dorsal row of teeth in females, upper margin nearly straight in males (WiLliams, 1984).

Material examined. CCDGR. -43 ovig. 우; $67 ㅇ ㅜ ; 34$ ㄱ.

Measurements. CL: ovig. ๆ $2.04-3.47 \mathrm{~mm}$; ๆ $1.32-1.48 \mathrm{~mm}$; ठึ 1.16-2.09 $\mathrm{mm}$.

Habitat. Coastal waters in sponges, among shells, dead coral, hydroids, and on seagrass beds; up to $44 \mathrm{~m}$ depth (Williams, 1984).

General distribution. Subtropical and tropical Atlantic. From North Carolina, USA, to Buenos Aires, Argentina (ChristofFersen, 1998; RodrígueZAlmaraz et al., 2000), in the Western Atlantic; including the Gulf of Mexico, the Antilles, Venezuela and Guyana (Williams, 1984). In the Eastern Atlantic, from Western Sahara to Congo (Williams, 1984; Christoffersen, 1998).

Distribution in Venezuela. Cubagua Island (HERNÁNDEZ-Ávila et al., 2007). Now in Paraguaná Peninsula, Falcón state.

\section{Panopeus occidentalis Saussure, 1857}

Diagnosis. Carapace approximately $2 / 3$ as long as wide, regions well marked, surface sparingly granulated; carapace convex especially in gastric region; front narrow, advanced; anterolateral margins with 5 teeth, first 2 coalescent, second anterolateral tooth narrower and separated by deeper sinus from first tooth, third to fifth teeth thicker, more prominent and widely separated, third blunt, forming almost right angle at tip (ABELE \& Kim, 1986).

Material examined. CCDGR. $-7 \hat{\jmath}$.

Measurements. CW: $11.4-19.4 \mathrm{~mm}$. CL: $8.3-13.5 \mathrm{~mm}$

Habitat. Between rocks, on mangrove roots, sponges, ascidians, and seaweed, on pilings of piers along shores; shallow waters up to $18.2 \mathrm{~m}$ depth (WiLliams, 1984). Now on seagrass beds.

General distribution. Western Atlantic. From North Carolina, USA, to Rio Grande do Sul, Brazil, including Bermuda, Central America, Antilles, and northern South America (Williams, 1984; Melo, 1999).

Distribution in Venezuela. Cubagua Island (HernáNDEZ-ÁviLA et al., 2007), Los Frailes archipelago (TAgLiafico et al., 2005), and Orinoco River Delta (Pereira et al., 2004). Now in Paraguaná Peninsula, Falcón state.

\section{Processa fimbriata Manning \& Chace, 1971}

Diagnosis. Antennal spine present. Stylocerite with lateral spinule. Second pereiopods asymmetrical. Right second pereiopod with 14-16 meral and 31-40 carpal articles, left second pereiopod with 4-6 meral and 15-18 carpal articles. Carpus of fifth pereiopod shorter than propodus. Fifth abdominal somite with posterolateral spine (MANNING \& CHACE, 1971).

Material examined. CCDGR. -1 ovig. $\circ ; 2$.

Measurements. CL: ovig. ㅇ $10.89 \mathrm{~mm}$; ㅇ $3.19-4.18 \mathrm{~mm}$.

Habitat. Shallow waters up to $37 \mathrm{~m}$ depth; on broken shells, corals, and sponges (MANNING \& CHACE, 1971). Now on seagrass beds.

General distribution. Western Atlantic. From North Carolina, USA, to Rio de Janeiro, Brazil (Manning \& Chace, 1971). Including the Bahamas, Puerto Rico (Manning \& CHACE, 1971), the Gulf of Mexico (Chace, 1972), Cuba (Martínez-Iglesias et al., 1996) and Tobago (СHACE, 1972).

Distribution in Venezuela. Cubagua Island (HeRnández-ÁviLA et al., 2007), Los Roques National Park (B. López-Sánchez, unpubl. data). Now in Paraguaná Peninsula, Falcón state. 